\title{
Sektor rolno-spożywczy jako priorytet w strategiach inteligentnych specjalizacji państw Unii Europejskiej
}

\begin{abstract}
Marcin Kardas*
$W$ artykule dokonano analizy strategii inteligentnych specjalizacji państw Unii Europejskiej (UE28) oraz ich specjalizacji naukowej i technologicznej pod katem sektora rolno-spożywczego. Zidentyfikowano 24 państwa, które określity sektor rolno-spożywczy w strategiach inteligentnych specjalizacji jako obszary priorytetowe (na poziomie krajowym lub regionalnym) oraz dokonano analizy specjalizacji naukowych i technologicznych tych państw w zakresie sektora rolno-spożywczego na podstawie analizy bibliometrycznej artykułów naukowych oraz zgtoszeń patentowych, a także danych dotyczacych finansowania i zatrudnienia w sektorze badawczo-rozwojowym. Na podstawie ww. analizy wyodrębniono trzy grupy państw (liderzy skali, liderzy specjalizacji i państwa budujace skalę lub specjalizację) oraz główne wyzwania zwiazane z ich strategiami inteligentnych specjalizacji w kontekście sektora rolno-spożywczego. Omówiono także najważniejsze ograniczenia związane z przyjęta metoda analizy $i$ zaproponowano kierunki dalszych badań $w$ tym zakresie.
\end{abstract}

Słowa kluczowe: sektor rolno-spożywczy, inteligentne specjalizacje, bibliometria, artykuły naukowe, zgłoszenia patentowe, Unia Europejska.

Nadesłany: 20.11.2016 | Zaakceptowany do druku: 02.12.2016

\section{Agri-Food Industry as Priority in Smart Specialization Strategies in EU Member States}

The article presents the analysis of the smart specialization strategy in the EU Member States (EU28) and their research and innovation specializations from the perspective of agri-food industry. 24 countries were identified that indicated agri-food industry in the smart specialization strategies (at the national or regional level). Then research and technological potential and specialization of these countries in agri-food industry were analyzed. On that basis three groups of countries (leaders of scale, leaders of specialization and countries building scale or specialization) and the main challenges associated with their smart specialization strategies in the context of agri-food industry were identified. The article also discusses the limitations of the adopted method of analysis and proposes directions for further research in this area.

Keywords: agri-food industry, smart specialisation, bibliometry, articles, patent applications, European Union.

Submitted: 20.11.2016 | Accepted: 02.12.2016

JEL: O38, O13

* Marcin Kardas - dr, Wydział Zarządzania, Uniwersytet Warszawski,

Adres do korespondencji: Wydział Zarządzania, Uniwersytet Warszawski, ul. Szturmowa 1/3,02-678 Warszwa; e-mail: mkardas@wz.uw.edu.pl. Ministry of Science
and Higher Education Republic of Poland
The creation of the English-language version of these publications is financed in the framework of contract No. 768/P-DUN/2016 by the Ministry of Science and Higher Education committed to activities aimed at the promotion of education. 


\section{Wstęp}

Sektor rolno-spożywczy stanowi źródło wzrostu oraz konkurencyjności wielu państw rozwiniętych i rozwijających się, a także ważne pole opracowywania i wdrażania innowacyjnych rozwiązań zapewniających wzrost produktywności, przyjazność dla środowiska naturalnego i zrównoważony rozwój (OECD, 2015a, s. 167). Na wzrost produktywności oraz zrównoważony rozwój sektora rolno-spożywczego wpływ mają różne polityki, w tym naukowo-technologiczna i innowacyjna (OECD, 2015b, s. 4). Znaczenie sektora rolno-spożywczego w kontekście badań i innowacji potwierdza duża popularność oraz wskazywanie przez przedsiębiorców organizacji badawczych i pozarządowych jako obszarów priorytetowych zwiazanych z tym sektorem w strategiach inteligentnych specjalizacji (Cacicchi i Stancova, 2016, s. 26-27). Strategie inteligentnych specjalizacji powinny być osadzone w potencjale naukowo-technologicznym i gospodarczym, zaś ich tworzenie powinno wpisywać się w prowadzenie tzw. polityk opartych na dowodach (ang. evidence-based policies), które znajdują oparcie w wynikach badań i analiz. W efekcie, przy tworzeniu i identyfikowaniu priorytetów tematycznych powinno korzystać się z analiz bibliometrycznych publikacji naukowych, patentów i ich zgłoszeń, a także analiz danych statystycznych dotyczących działalności innowacyjnej i gospodarczej (Foray i in., 2012, s. 28; OECD, 2013, s. 151). Wykorzystanie tych analiz do identyfikowania specjalizacji naukowych, technologicznych i gospodarczych w państwach i ich wybranych regionach pod katem tworzenia strategii inteligentnych specjalizacji było przedmiotem projektu realizowanego w latach 2010-2012 przez Organizację Współpracy Gospodarczej i Rozwoju (OECD, 2013), a także jest przedmiotem aktywności i wielu opracowań powstałych $\mathrm{w}$ ramach platformy inteligentnej specjalizacji (S3 Platform), prowadzonej przez Instytut Perspektywicznych Studiów Technologicznych (IPTS) w Sewilli. W Polsce analizy te były przedmiotem realizowanego w latach 2013-2015 projektu Narodowy Program Foresight - wdrożenie wyników (Czaplicka-Kolarz i in., 2013; Rogut i Piasecki, 2013; Nazarko i in., 2013). Prace te wykazały dużą przydatność stosowania analiz bibliometrycznych, zwłaszcza danych dotyczących patentów, do identyfikowania potencjalnych obszarów specjalizacji naukowych i technologicznych, ale również wskazały na wiele ograniczeń związanych z wykorzystaniem tych metod, w tym ograniczeń związanych $\mathrm{z}$ dostępnością danych. Zagadnienia sektora rolno-spożywczego $\mathrm{w}$ odniesieniu do strategii inteligentnych specjalizacji w państwach Unii Europejskiej były dotychczas przedmiotem opracowań dotyczących głównie porównywania priorytetów tematycznych w strategiach inteligentnych specjalizacji, zwykle jako jeden $\mathrm{z}$ zidentyfikowanych obszarów priorytetowych na poziomie państw lub regionów (Sorvik i Kleibrink, 2015, s. 7; Cacicchi i Stancova, 2016, s. 26-27).

$\mathrm{W}$ artykule wykorzystano analizę bibliometryczną publikacji naukowych i zgłoszeń patentowych oraz danych statystycznych dotyczących działalności badawczo-rozwojowej do próby odpowiedzi na pytanie: „Czy priorytety dotyczące sektora rolno-spożywczego wskazane w strategiach inteligentnych specjalizacji państw i regionów Unii Europejskiej znajduja odzwierciedlenie w potencjale i specjalizacji naukowo-technologicznej tych państw?". W celu odpowiedzi na tak postawione pytanie w pierwszej kolejności zidentyfikowano państwa i regiony, które wskazały sektor rolno-spożywczy jako obszary inteligentnych specjalizacji. Nastepnie przedstawiono i przeanalizowano dane dotyczące ich aktywności naukowej i technologicznej w obszarze sektora rolno-spożywczego, w szczególności dane dotyczące publikacji naukowych, zgłoszeń patentowych oraz dane dotyczące finansowania i zatrudnienia $\mathrm{w}$ działalności badawczo-rozwojowej. W końcowej części artykułu przedstawiono wnioski wynikające z przeprowadzonych analiz, w tym korzyści i ograniczenia związane $z$ wykorzystaniem technik bibliometrycznych do tego typu analiz.

\section{Strategie inteligentnych specjalizacji - istota, klasyfikacje i obszary specjalizacji}

W dokumentach Komisji Europejskiej, a także w literaturze poświęconej strategiom inteligentnych specjalizacji wskazuje się, że identyfikowanie priorytetów w ramach tych strategii odbywa się w tzw. procesie przedsiębiorczego odkrywania (Foray i in., 2012, s. 20). Proces ten jest 
wyrazem ewolucji od podejścia odgórnego do określania priorytetów na rzecz podejścia oddolnego, w którym akcentuje się znaczenie różnych interesariuszy (np. przedsiębiorców, organizacji pozarządowych) oraz pomocniczą (drugoplanową) rolę instytucji publicznych (Kardas, 2015, s. 74). W procesie tworzenia strategii inteligentnych specjalizacji przy identyfikowaniu priorytetów interesariusze mają pełną swobodę w sposobie definiowania priorytetów. Niemniej jednak wskazuje się, że priorytety te nie powinny być określane w kategoriach sektorów przemysłu, dziedzin nauki bądź technologii, ale powinny integrować wymiar gospodarczy, technologiczny i naukowy (Foray i Goenaga, 2013, s. 3-4). W praktyce trudno jest definiować priorytety tematyczne w całkowitym oderwaniu od dostępnych i znanych od wielu lat systemów klasyfikacji, zwłaszcza gdy w myśl polityki opartej na dowodach niezbędne jest m.in. odwołanie się do analiz danych statystycznych agregowanych zgodnie z tymi klasyfikacjami. Tym samym klasyfikacje te nie powinny stanowić punktu docelowego, ale mogą stanowić cenny punkt wyjścia $\mathrm{w}$ procesie tworzenia strategii inteligentnych specjalizacji. Wybrane międzynarodowe klasyfikacje nauki, technologii i działalności gospodarczej, w tym w odniesieniu do sektora rolno-spożywczego, zostały przedstawione w tabeli 1.

Klasyfikacje przedstawione w tabeli 1 stanowią punkt wyjścia do opracowywania innych klasyfikacji, np. na poziomie państw, dzięki czemu umożliwiają porównywanie danych między różnymi państwami (np. z klasyfikacją ISIC rev. 4 zgodna jest Statystyczna Klasyfikacja Działalności we Wspólnocie Europejskiej (NACE rev. 2) oraz Polska Klasyfikacja Działalności (PKD 2007)). Poza wspomnianymi klasyfikacjami są także inne, tworzone na potrzeby konkretnych badań i analiz, bądź realizacji określonych celów polityczno-gospodarczych. Należy do nich m.in. podział na Kluczowe Technologie Wspomagające (ang. Key Enabling Technologies, KETs) zaproponowany przez Komisję Europejską. Kluczowe Technologie Wspomagające mają charakter przekrojowy, tzn. łączą i przenikają przez różne tradycyjne obszary technologiczne oraz produkcyjne. W ramach tego podziału wyróżniono 6 obszarów Kluczowych Technologii Wspomagających, zaś technologie dotyczące żywności zostały w nich ujęte w ramach tzw. biotechnologii przemysłowej (ang. industrial biotechnology) (Van de Velde i in., 2015, s. 46). Słabością klasyfikacji przedstawionych w tabeli 1 jest ich jednowymiarowość, ponieważ każda obejmuje tylko jeden określony wymiar tj. gospodarczy, technologiczny albo naukowy. Wprawdzie ich zintegrowaniu służą różne mapy konwersyjne, które pokazują wzajemne zależności i powiązania między tymi wymiarami, ale mapy te zwykle odwołują się do ocen jakościowych (eksperckich) i dają tylko ograniczony oraz uproszczony obraz wzajemnych relacji i powiązań tych wymiarów (Foray i in., 2012, s. 29; OECD, 2013, s. 163; Czaplicka-Kolarz i in., 2013, s. 37).

Próbą rozwiązania tego problemu było stworzenie przez Wspólne Centrum Badawcze Komisji Europejskiej w Sewilli narzędzia pod nazwą EYE@RIS3. W ramach powyższego zaproponowane zostały następujące rodzaje klasyfikacji:

- potencjału badawczo-innowacyjnego oraz potencjału rynkowego i biznesowego (14 kategorii, w tym jedna dotycząca sektora rolno-spożywczego, obejmująca 4 podkategorie zgodne z ISIC rev. 4 i NACE rev. 2),

- priorytetów Unii Europejskiej (11 kategorii, przy czym zagadnienia dotyczące sektora rolno-spożywczego, wpisuja się w 5 z nich) (Sorvik i Kleibrink, 2015, s. 6).

Narzędzie to pozwala ,sprowadzić do wspólnego mianownika" definiowane w różny sposób krajowe i regionalne inteligentne specjalizacje. Przyporządkowania tego dokonują osoby z krajowych lub regionalnych instytucji publicznych wspierających (koordynujących) procesy opracowywania strategii inteligentnych specjalizacji. Wykorzystywanie tego narzędzia jest bardzo przydatne na polu identyfikowania partnerów i budowania międzynarodowej sieci współpracy w tych samych lub powiązanych obszarach tematycznych, ale na polu analitycznym musi uwzględniać ograniczenia związane głównie z dużym zróżnicowaniem sposobu opisu priorytetów w strategiach inteligentnych specjalizacji oraz subiektywnym charakterem przyporządkowania do poszczególnych kategorii. Mimo tego, jest to nadal najbardziej rozbudowane narzędzie i system klasyfikacji inteligentnych specjalizacji w ujęciu międzynarodowym. 


\begin{tabular}{|c|c|c|}
\hline Nazwa klasyfikacji & Podstawowy podzial & Sektor rolno-spożywczy \\
\hline $\begin{array}{l}\text { Dziedziny nauki i techniki } \\
\text { OECD } \\
\text { (Field of Science and } \\
\text { Technology, FoS 2007) }\end{array}$ & $\begin{array}{l}6 \text { dziedzin nauki i } 1 \text { dziedzina } \\
\text { sztuki (w ramach dziedzin } \\
\text { głównych wyróżniono dziedziny } \\
\text { szczegółowe) }\end{array}$ & $\begin{array}{l}\text { Jedna z dziedzin głównych (4. pozycja) to „Nauki rolnicze” (ang. agricultural sciences), } \\
\text { obejmująca następujące dziedziny szczegółowe: } \\
\text { • rolnictwo, leśnictwo i rybołówstwo, } \\
\text { • nauka o zwierzętach i nabiale, } \\
\text { • nauki weterynaryjne, } \\
\text { - biotechnologia rolnicza, } \\
\text { - inne nauki rolnicze. }\end{array}$ \\
\hline $\begin{array}{l}\text { Nomenklatura dla analizy } \\
\text { i porównań programów } \\
\text { i budżetów naukowych } \\
\text { (Nomenclature for the Analysis } \\
\text { and Comparison of Scientific } \\
\text { Programmes and Budgets, } \\
\text { NABS 2007) }\end{array}$ & $\begin{array}{l}14 \text { kategorii (NABS 2007) } \\
\text { prezentujących cele społeczno- } \\
\text { ekonomiczne związane } \\
\text { z finansowaniem badań } \\
\text { naukowych }\end{array}$ & $\begin{array}{l}\text { Rozdział } 8 \text { - Rolnictwo (w wersji z } 1992 \text { roku rozdział } 6 \text { - Produkcja i technika } \\
\text { rolnicza). } \\
\text { Do tego celu społeczno-ekonomicznego zalicza się prace B+R należące do poniższych } \\
\text { obszarów: promocja rolnictwa, leśnictwa, rybołówstwa i produkcji żywności, nawozy } \\
\text { chemiczne, substancje biobójcze, biologiczna kontrola szkodników, mechanizacja } \\
\text { rolnictwa, skutki działalności rolniczej i leśnej dla środowiska, rozwój wydajności } \\
\text { w produkcji i technologii żywności. }\end{array}$ \\
\hline $\begin{array}{l}\text { Międzynarodowa Klasyfikacja } \\
\text { Patentowa (International } \\
\text { Patent Classification, IPC } \\
\text { 2012.01) }\end{array}$ & 8 działów, klasy i podklasy & $\begin{array}{l}\text { Dział A - Podstawowe potrzeby ludzkie; klasy: } \\
\text { A-01 - rolnictwo, leśnictwo, hodowla zwierząt, lowiectwo, zakładanie sideł, rybołówstwo, } \\
\text { A-21 - piekarnictwo, urządzenia do produkcji lub przetwarzania ciasta, do wypieków, } \\
\text { A-22 - ubój, przerób mięsa, przerób drobiu lub ryb, } \\
\text { A-23 - żywność lub środki spożywcze, ich przerób nie objęty przez inne klasy. }\end{array}$ \\
\hline $\begin{array}{l}\text { Międzynarodowa Standardowa } \\
\text { Klasyfikacja Rodzajów } \\
\text { Działalności (International } \\
\text { Standard Industrial } \\
\text { Classification of all Economic } \\
\text { Activities, ISIC rev. 4) }\end{array}$ & $\begin{array}{l}21 \text { sekcji obejmujących dywizje, } \\
\text { grupy i klasy }\end{array}$ & $\begin{array}{l}\text { Sekcja A (Rolnictwo, leśnictwo i rybactwo) } \\
01 \text { - uprawy rolne, chów i hodowla zwierząt, łowiectwo, włączając działalność usługową, } \\
02 \text { - leśnictwo i pozyskiwanie drewna, } \\
03 \text { - rybactwo. } \\
\text { Sekcja C (Przetwórstwo): } \\
10 \text { - żywność, } \\
11 \text { - napoje, } \\
12 \text { - wyroby tytoniowe. }\end{array}$ \\
\hline
\end{tabular}


Narzędzie EYE@RIS3 było wykorzystywane do przeglądu priorytetów wskazanych przez europejskie regiony i państwa w strategiach inteligentnej specjalizacji (Sorvik i Kleibrink, 2015, s. 6). Było także wykorzystywane do oceny inteligentnych specjalizacji pod kątem sektora spożywczego (Cacicchi i Stancova, 2016, s. 26-27). W większości przypadków sektor rolno-spożywczy nie jest określany wprost w tych strategiach, ale pośrednio jako element innych, bardziej szerszych tematycznie priorytetów, takich jak biogospodarka, bądź priorytetów powiązanych z turystyką, gospodarką wodną oraz technologiami informacyjno-komunikacyjnymi. Według danych pochodzących z EYE@RIS3 (na dzień 4 listopada 2016 r.) priorytety związane z sektorem rolno-spożywczym zostały wskazane jako inteligentne specjalizacje na poziomie krajowym przez Cypr, Chorwację, Danię, Estonię, Irlandię, Litwę, Maltę, Polskę, Portugalię, Słowenię i Węgry. Natomiast na poziomie regionów specjalizację taką zidentyfikowały regiony z: Austrii (1 region), Belgii (1 region), Czech (1 region), Danii (3), Finlandii (8), Francji (15), Grecji (8), Hiszpanii (9), Holandii (5), Niemiec (4), Polski (10), Portugali (5), Rumunii (1), Szwecji (3), Wielkiej Brytanii (3) i Włoch (12). Warto jednak zaznaczyć, że w niektórych państwach nie tworzono strategii inteligentnych specjalizacji na poziomie krajowym (np. Holandia, Belgia) bądź na poziomie regionalnym (np. Bułgaria) oraz nie wszystkie państwa i regiony wprowadziły dane dotyczace ich priorytetów (np. z Austrii tylko jeden region). W sumie, na 28 państw należących obecnie do Unii Europejskiej, sektor rolno-spożywczy jako obszar priorytetowy w strategiach inteligentnych specjalizacji wskazano w 24 państwach (na poziomie krajowym lub przynajmniej jednego regionu). Poza tą grupą były Bułgaria, Luksemburg, Łotwa i Słowacja.

\section{Sposoby identyfikowania specjalizacji naukowych i technologicznych}

Do analizy specjalizacji naukowych i technologicznych mogą zostać wykorzystane bazy bibliometryczne Scopus (Elsevier) oraz Web of Science (Thomson Reuters). W niniejszym opracowaniu wykorzystano bazę Scopus, zaś do przetwarza- nia danych - program Scival. Do porównań wykorzystano dane dotyczące artykułów naukowych. Baza Scopus umożliwia klasyfikację publikacji naukowych w ramach klasyfikacji dziedzin nauki i techniki OECD (FoS 2007), dzięki czemu możliwe jest ich odniesienie do danych dziedzinowych dotyczących nakładów finansowych na badania i zatrudnienie pracowników w sektorze badawczo-rozwojowym pochodzących z bazy Eurostat i bazy OECD.Stat. Dane dotyczące zgłoszeń patentowych opierają się na Międzynarodowej Klasyfikacji Patentów (IPC), pochodzą z bazy Eurostat i dotyczą zgłoszeń patentowych w Europejskim Urzędzie Patentowym (ang. European Patent Office, EPO). W przypadku zgłoszeń patentowych przypisanie do danego kraju odbywa się według siedziby wynalazcy i stosowana jest metoda zliczania udziałowego (ang. fractional counting). Dane dotyczące finansowania działalności badawczo-rozwojowej przedsiębiorstw (STAN R\&D expenditures in industry), zatrudnienia oraz eksportu pochodzą natomiast $\mathrm{z}$ bazy OECD.Stat i klasyfikowane są zgodnie $\mathrm{z}$ ISIC rev. 4 . W ramach prowadzonych analiz i porównań ograniczono się do danych przyporządkowanych zgodnie z klasyfikacjami i definicjami przedstawionymi w tabeli 1 . Na wykresach dane wyrażone zostały w euro w cenach bieżących lub w USD według parytetu siły nabywczej w cenach bieżących.

Analizą objęto dane z lat 1996-2015 oraz 28 państw należących w 2015 roku do Unii Europejskiej (UE28), a w wybranych przypadkach także w skali globalnej (całego świata). Niemniej jednak w większości analizowanych przypadków zakres czasowy obejmował krótsze okresy z uwagi na ograniczenia dostępnych danych, zwłaszcza danych dotyczących zgłoszeń patentowych (1996-2012), a także nakładów finansowych na badania i zatrudnienie pracowników w sektorze badawczo-rozwojowym (głównie 2008-2013): dane w bazie Eurostat i bazie OECD.Stat dostępne są dla kilku państw, głównie Europy ŚrodkowoWschodniej, brakuje natomiast danych dla państw z Europy Zachodniej.

Ocena działalności naukowej i technologicznej państw oraz regionów może być dokonywana na bazie mnożników aktywności naukowej dotyczących liczby publikacji naukowych bądź wskaźników dotyczących cytowań opublikowanych prac, które odnoszą się do gatunku (jakości, wpływu) 
badań naukowych, takich jak ogólna liczba cytowań czy liczba cytowań danego autora podzielona przez liczbę opublikowanych przez niego tekstów (Marszakowa-Szajkiewicz, 2009, s. 119; Klincewicz, 2008, s. 18-20; Olechnicka i Płoszaj, 2008, s. 17). W wymiarze ewaluacyjnym dane bibliometryczne mogą być także wykorzystywane do obliczania wskaźników specjalizacji (odzwierciedlające udział publikacji na określony temat we wszystkich publikacjach) oraz wskaźników konkurencyjności (porównujące względne przewagi różnych osób lub grup, wynikające ze specjalizacji w danym obszarze badawczym) (Klincewicz, 2012, s. 96; OECD, 2013, s. 154). W niniejszym artykule oparto się na obliczeniach podstawowych wskaźników bibliometrycznych, takich jak liczba artykułów naukowych, liczba cytowań na artykuł naukowy, a także liczba artykułów naukowych znajdujących się w grupie $10 \%$ najwyżej cytowanych artykułów, liczba artykułów publikowanych w $10 \%$ czasopism o najwyższym poziomie cytowań oraz artykułów, których współautor pochodzi z innego pań stwa. Ponadto, do oceny wpływu publikacji wykorzystano wskaźnik ważonego dziedzinowo wpływu cytowań (ang. field-weighted citation impact, FWCI), który odnosi liczbę cytowań danej publikacji do średniej liczby cytowań podobnych publikacji na świecie, tj. tego samego typu (np. artykuł naukowy), opublikowanych w tym samym roku i w tej samej dziedzinie (Colledge i Verlinde, 2014, s. 64). Do oceny specjalizacji i konkurencyjności publikacji naukowych i zgłoszeń patentów wykorzystany został wskaźnik ujawnionej przewagi technologicznej RTA (ang. revealed technological advantage). Wartość tego wskaźnika powyżej 1 wskazuje, że udział artykułów naukowych lub zgłoszeń patentów w danej dziedzinie do artykułów naukowych lub zgłoszeń patentowych ogółem w danym państwie był większy niż ten udział w państwach należących do Unii Europejskiej (UE28) lub innej grupie będącej punktem odniesienia (Klincewicz, 2012, s. 139; OECD, 2013, s. 156).

\section{Sektor rolno-spożywczy w wybranych państwach europejskich - specjalizacje naukowe i technologiczne}

W latach 1996-2012 w skali globalnej (cały świat) państwa UE28 wyróżniały się ujawnioną przewagą naukową i technologiczna w zakresie sektora rolno-spożywczego (odpowiednio: 1,05 oraz 1,24). Na rysunku 1 przedstawiono wartości wskaźników ujawnionej przewagi naukowej (oś

Rysunek 1. Specjalizacja naukowa i technologiczna w zakresie sektora rolno-spożywczego państw UE28 w latach 1996-2012

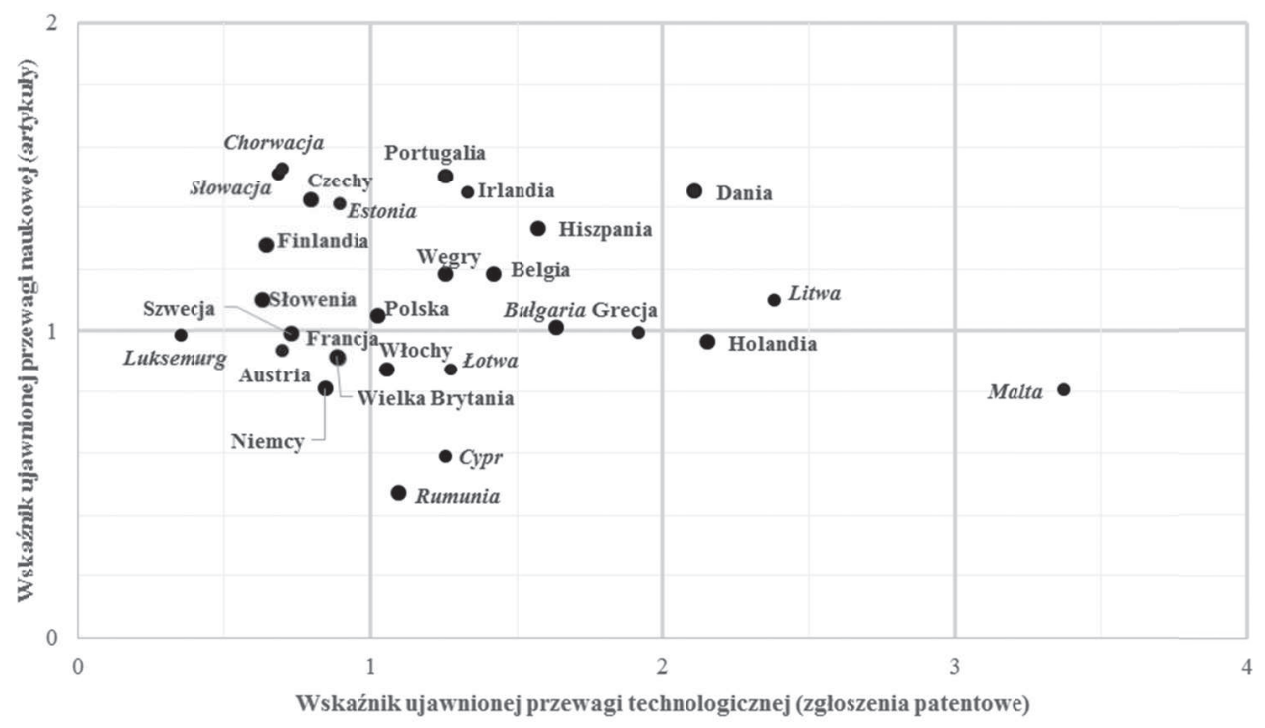

Źródło: opracowanie własne na podstawie danych Scival [23.06.2016] i Eurostat [4.11.2016]. 
pionowa) i technologicznej (oś pozioma) państw UE28 w latach 1996-2012 (punkt odniesienia - UE28).

Z uwagi na małą liczbę zgłoszeń patentów w Europejskim Urzędzie Patentowym niektórych państw (Bułgaria, Chorwacja, Cypr, Estonia, Litwa, Luksemburg, Łotwa, Malta, Rumunia, Słowacja - zaznaczone kursywą na rysunku 1) ich wyniki mają wyłącznie charakter informacyjny i na ich podstawie nie należy wyciągać wniosków odnośnie do specjalizacji technologicznej (OECD, 2013, s. 153).

W latach 1996-2012 największą wartość wskaźnika ujawnionej przewagi naukowej (artykuły naukowe) miały: Chorwacja, Słowacja, Portugalia, Dania, Czechy, Estonia i Irlandia (wszystkie państwa powyżej 1,4), zaś ujawnionej przewagi technologicznej (zgłoszenia patentów): Dania i Holandia (udział zgłoszeń patentów dotyczących sektora rolno-spożywczego był dwa razy wyższy niż ten udział w grupie UE28). W latach 1996-2012 względna przewaga naukową oraz technologiczną (oba wskaźniki powyżej 1) w zakresie sektora rolnospożywczego wyróżniała się Dania, a także Hiszpania, Irlandia, Belgia, Węgry, Grecja i Polska. Brak specjalizacji naukowej i technologicznej w świetle ww. wskaźników dotyczył Niemiec, Wielkiej Brytanii, Francji, Austrii i Szwecji (oba wskaźniki poniżej 1).

$\mathrm{W}$ tabeli 2 przedstawione zostały dane dotyczące liczby artykułów naukowych, liczby cytowań tych artykułów oraz zgłoszeń patentowych w latach 2002 i 2012 w państwach UE28. Liderami pod względem liczby artykułów naukowych oraz zgłoszeń patentowych w latach 1996-2012 były państwa, które wyróżniały się brakiem specjalizacji naukowej i technologicznej, tj. Niemcy, Wielka Brytania, Francja czy Włochy. Wyjątkiem jest Hiszpania, która wyróżniała się dużą liczbą artykułów naukowych i wysokimi wskaźnikami ujawnionej przewagi naukowej i technologicznej (ale mniejszą liczbą zgłoszeń patentowych niż Niemcy, Wielka Brytania, Francja czy Włochy). Interesującym przypadkiem jest także Holandia, wyróżniająca się ujawnioną przewagą technologiczną i dużą liczbą zgłoszeń patentowych (drugie miejsce w UE28). Z kolei państwa Europy Środkowo-Wschodniej, mimo względnej przewagi naukowej i technologicznej, miały mniejszą liczbę artykułów naukowych i patentów niż państwa $z$ Europy
Zachodniej. Brak specjalizacji naukowej i technologicznej w zakresie sektora rolnospożywczego według wskaźników ujawnionych przewag w odniesieniu do Niemiec, Francji, Wielkiej Brytanii i Włoch wynikał z dużej aktywności naukowej i patentowej $w$ innych dziedzinach niezwiązanych z sektorem rolno-spożywczym. Tym samym, państwa te dysponuja znaczącym potencjałem naukowo-technologicznym w sektorze rolno-spożywczym, ale nie jest on odzwierciedlony we wskaźnikach ujawnionych przewag naukowych i technologicznych. Duże różnice między państwami Europy Zachodniej oraz Europy Środkowo-Wschodniej dotyczyły zwłaszcza liczby zgłoszeń patentowych. Można to tłumaczyć różnicami związanymi z kontekstem kulturowo-instytucjonalnym, w tym specyficznymi uwarunkowaniami i doświadczeniami transformacji systemowej w państwach post-socjalistycznych. Mniejsza liczba zgłoszeń i patentów w Europejskim Urzędzie Patentowym wiązała się z relatywnie wysokimi kosztami patentowania za granica dla podmiotów z Europy Środkowo-Wschodniej, niższą kulturą prawną i świadomością korzyści wynikających z patentowania oraz koncentracją aktywności podmiotów $\mathrm{z}$ tych państw na rynkach krajowych (także ograniczania się do patentowania w krajowych urzędach patentowych). Z drugiej strony, można ich upatrywać również w strategiach dużych koncernów sektora rolnospożywczego z Europy Zachodniej, które aktywnie chronią swoje wynalazki dzięki patentom (np. Unilever NV i Unilever Plc, Danone SA).

Różnice między państwami Europy Zachodniej oraz Europy ŚrodkowoWschodniej widoczne są także w przypadku pozostałych wskaźników dotyczących artykułów naukowych i cytowań. Największe wartości wskaźników dotyczących liczby artykułów w grupie 10\% najwyżej cytowanych artykułów bądź artykułów w czasopismach o najwyższym poziomie cytowalności dotyczyły Wielkiej Brytanii, Niemiec i Francji, a także Hiszpanii, Włoch i Holandii. Niemniej jednak, w przypadku wskaźników względnych określających udział określonych artykułów w liczbie artykułów ogółem wyróżniały się Holandia, Dania i Szwecja (w 2002 i 2012 roku powyżej 10\%). W przypadku Niemiec i Francji, a także Portugali, udział ten wynosił w 2012 roku 8\%, a Hiszpanii $7 \%$. Z kolei w przypadku Polski, 
Tabela 2. Aktywność naukowa i technologiczna państw Unii Europejskiej w zakresie sektora rolno-spożywczego w latach 2002 i 2012

\begin{tabular}{|c|c|c|c|c|c|c|c|c|c|c|c|c|c|c|c|c|}
\hline Państwo|rok & \multicolumn{2}{|c|}{ Artykuly naukowe } & \multicolumn{2}{|c|}{$\begin{array}{l}\text { Cytowania artykulów } \\
\text { naukowych (bez } \\
\text { samocytowań) }\end{array}$} & \multicolumn{2}{|c|}{$\begin{array}{c}\text { Cytowania na } \\
\text { artykut naukowy } \\
\text { (bez samocytowań) }\end{array}$} & \multicolumn{2}{|c|}{$\begin{array}{l}\text { Artykuly w grupie } 10 \% \\
\text { najuyżej cytowanych } \\
\text { artykutów }\end{array}$} & \multicolumn{2}{|c|}{$\begin{array}{c}\text { Artykuly w 10\% } \\
\text { najwyżej cytowanych } \\
\text { czasopismach }\end{array}$} & \multicolumn{2}{|c|}{$\begin{array}{l}\text { Artykuly naukowe } \\
\text { z zagranicznym } \\
\text { wspólautorem }\end{array}$} & \multicolumn{2}{|c|}{$\begin{array}{c}\text { Czasopisma w Scimago } \\
\text { Journal\&Country Rank } \\
\text { (journals) } \\
\end{array}$} & \multicolumn{2}{|c|}{\begin{tabular}{|c|} 
Zgloszenia patentowe \\
w Europejskim Urzedzie \\
Patentowym (EPO)
\end{tabular}} \\
\hline Austria & 501 & 1265 & 11956 & 9475 & 23,86 & 7,49 & 47 & 104 & 68 & 466 & 208 & 847 & 6 & 11 & 21,18 & 39,63 \\
\hline Bułgaria & 138 & 393 & 1794 & 803 & 13,00 & 2,04 & 5 & 6 & 1 & 21 & 41 & 144 & 1 & 8 & 1 & 0,33 \\
\hline Chorwacja & 214 & 525 & 1878 & 1688 & 8,78 & 3,22 & 4 & 16 & 6 & 56 & 47 & 213 & 6 & 12 & 1 & 0,5 \\
\hline Cypr & 7 & 60 & 128 & 422 & 18,29 & 7,03 & 0 & 7 & 0 & 13 & 2 & 49 & 0 & 0 & 1 & 0 \\
\hline Czechy & 524 & 1605 & 6296 & 5772 & 12,02 & 3,60 & 13 & 47 & 38 & 229 & 135 & 544 & 7 & 21 & 1,84 & 6,75 \\
\hline Finlandia & 809 & 1271 & 20694 & 9608 & 25,58 & 7,56 & 78 & 99 & 108 & 486 & 233 & 718 & 13 & 14 & 29,55 & 37,61 \\
\hline Francja & 3178 & 6178 & 72690 & 44416 & 22,87 & 7,19 & 240 & 513 & 499 & 2635 & 1094 & 3615 & 39 & 44 & 188,95 & 204,91 \\
\hline Grecja & 499 & 979 & 13149 & 5980 & 26,35 & 6,11 & 53 & 68 & 22 & 217 & 136 & 409 & 1 & 5 & 2,24 & 5,72 \\
\hline Hiszpania & 2808 & 6502 & 57714 & 43323 & 20,55 & 6,66 & 167 & 464 & 325 & 2146 & 722 & 3057 & 12 & 27 & 50,61 & 59,35 \\
\hline Holandia & 1428 & 3088 & 41774 & 30209 & 29,25 & 9,78 & 156 & 391 & 230 & 1556 & 593 & 1967 & 129 & 159 & 178,06 & 254,74 \\
\hline Irlandia & 394 & 918 & 8862 & 8262 & 22,49 & 9,00 & 30 & 102 & 29 & 322 & 126 & 528 & 3 & 3 & 6,67 & 8,68 \\
\hline Polska & 1012 & 2351 & 7997 & 7497 & 7,90 & 3,19 & 12 & 60 & 37 & 256 & 207 & 592 & 24 & 40 & 1,29 & 17,16 \\
\hline \begin{tabular}{|l|l|} 
Portugalia \\
\end{tabular} & 479 & 1551 & 11191 & 10793 & 23,36 & 6,96 & 30 & 127 & 48 & 496 & 189 & 842 & 0 & 3 & 1,33 & 7,57 \\
\hline Rumunia & 29 & 580 & 622 & 1348 & 21,45 & 2,32 & 3 & 16 & 2 & 47 & 19 & 136 & 0 & 11 & 0 & 6,43 \\
\hline Stowenia & 139 & 398 & 1548 & 1404 & 11,14 & 3,53 & 2 & 19 & 5 & 80 & 31 & 206 & 0 & 1 & 1 & 4,83 \\
\hline Stowacja & 190 & 449 & 1610 & 2083 & 8,47 & 4,64 & 2 & 11 & 4 & 30 & 62 & 186 & 5 & 7 & 0,42 & 1 \\
\hline Szwecja & 1184 & 2160 & 34859 & 18953 & 29,44 & 8,77 & 123 & 241 & 228 & 1081 & 479 & 1383 & 6 & 5 & 45,56 & 73,85 \\
\hline Węgry & 400 & 743 & 4063 & 3898 & 10,16 & 5,25 & 8 & 40 & 10 & 169 & 106 & 351 & 5 & 13 & 10,85 & 10,67 \\
\hline \begin{tabular}{|l|} 
Wielka Brytania \\
\end{tabular} & 4829 & 8308 & 127020 & 66917 & 26,304 & 8,05 & 452 & 791 & 985 & 4016 & 1789 & 5223 & 272 & 336 & 131,64 & 131,39 \\
\hline \begin{tabular}{|l|} 
Włochy \\
\end{tabular} & 2118 & 5077 & 41963 & 32176 & 19,813 & 6,34 & 122 & 331 & 192 & 1683 & 560 & 2275 & 21 & 33 & 153,15 & 149,25 \\
\hline
\end{tabular}

Żródło: opracowanie własne na podstawie danych Scival [23.06.2016] oraz Eurostat [4.11.2016]. 
Czech, Słowacji i Węgier udział ten wynosił odpowiednio 3\%, 3\%, 2\% i 5\%. W 2012 roku powyżej $40 \%$ artykułów z Holandii, Niemiec, Francji i Danii zostało opublikowanych w czasopismach zaliczanych do $10 \%$ najwyżej cytowanych czasopism (tj. o największym oddziaływaniu), a w odniesieniu do Polski, Czech, Słowacji i Węgier udział ten wynosił odpowiednio $11 \%, 14 \%, 7 \%$ i 23\%. Największą liczbę czasopism dotyczących rolnictwa w bazie Scientific Journal Rankings (SJR, według klasyfikacji dziedzinowej Scopus, a nie dziedzin nauk i techniki OECD) miały Wielka Brytania, Holandia i Niemcy, a także Francja i Polska. Artykuły z Holandii i Danii wyróżniały się wysokim poziomem zagranicznego współautorstwa - w 2012 roku było to 64\% artykułów, zaś w przypadku Polski, Czech, Słowacji i Węgier udział ten wynosił odpowiednio: $25 \%, 34 \%, 41 \%$ i $47 \%$.

Wpływ/oddziaływanie artykułów naukowych można także badać za pomocą liczby cytowań na artykuł oraz wskaźnika ważonego dziedzinowo wpływu cytowań (FWCI). Największą liczbą cytowań na artykuł w latach 2002 i 2012 wyróżniały się Szwecja, Holandia, Dania oraz Wielka Brytania. W przypadku państw o mniejszej liczbie artykułów wyniki te były zróżnicowane, ale generalnie wartości te były niższe dla państw z Europy Środowo-Wschodniej. Na rysunku 2 przedstawiono zmiany wpływu/ oddziaływania artykułów naukowych (FWCI) w relacji do ich liczby w latach 2009-2013 dla wybranych państw UE28 (wartość wskaźnika ważonego dziedzinowo wpływu cytowań (FWCI) powyżej 1 oznacza, że dany artykuł był cytowany częściej niż artykuły $z$ tej samej lub tych samych dziedzin i tego samego roku na świecie).

W 2012 roku wskaźnik ważonego dziedzinowo wpływu cytowań (FWCI) w Holandii $(1,75)$ i Danii $(1,68)$ był znacznie większy niż w Polsce $(0,84)$, Czechach $(0,84)$, Słowacji $(0,73)$ i Węgrzech $(0,93)$. Wskaźnik ten był również wyższy dla artykułów z Niemiec $(1,39)$, Wielkiej Brytanii $(1,59)$, Francji $(1,37)$, Włoch $(1,38)$ i Hiszpanii $(1,4)$. Potwierdza to wnioski wynikające $\mathrm{z}$ analizy innych wskaźników mówiące o wysokiej jakości artykułów naukowych (według przyjętych wskaźników) państw Europy Zachodniej, zwłaszcza Holandii i Danii. Różnice między ww. państwami dotyczą także wielkości nakładów na badania i rozwój. W 2012 roku według danych Eurostat nakłady ogółem na badania i rozwój sektora rolno-spożywczego w Holandii wyniosły 1,1 mld euro, zaś nakłady na ten cel w Polsce, Czechach, Słowacji i Węgrzech wyniosły łącznie ok. $365 \mathrm{mln}$ euro (brak danych uniemożliwia porównanie $\mathrm{z}$ innymi państwami Europy Zachodniej). Wielkość zatrudnienia wyrażona w pełnym ekwiwalencie czasu pracy (ang. full time equiva-

Rysunek 2. Zmiany wpływu/oddziaływania artykułów naukowych (FWCI) w relacji do ich liczby w latach 2009-2013

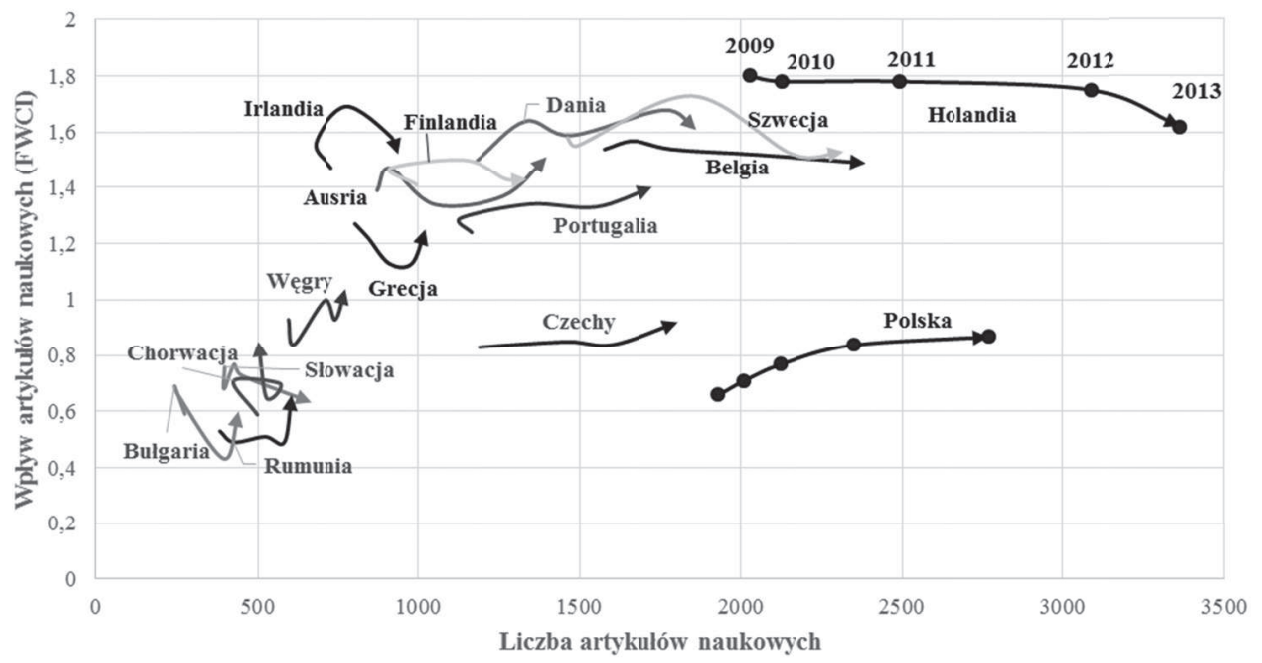

Źródło: opracowanie własne na podstawie danych Scival [23.06.2016].

Wydział Zarządzania UW ～DOI 10.7172/1733-9758.2016.22.3 
lent, FTE) w sektorze rolno-spożywczym w Holandii wyniosła 10 261, zaś w Polsce, Czechach, Słowacji i Węgrzech wyniosła łącznie 11752.

Na rysunku 3 przedstawiono porównanie wybranych wskaźników dotyczących aktywności naukowej ww. państw w przeliczeniu na jednego pracownika (według pełnego ekwiwalentu czasu pracy). Porównanie obejmuje Polskę, Węgry, Czechy, Słowację i Holandię (jedyne państwo z Europy Zachodniej, dla którego dostępne są dane o zatrudnieniu w sektorze rolno-spożywczym według klasyfikacji dziedzin nauki i techniki OECD w bazach Eurostat i OECD.Stat).

Wskaźniki aktywności naukowej w przeliczeniu na liczbę pracowników wskazuja na przewage Holandii z wyjątkiem liczby artykułów naukowych na pracownika, gdzie wyższą wartość wskaźnika w 2012 roku osiągnęły Czechy, Polska i Węgry. W przeliczeniu na pracownika artykuły naukowe z Czech wyróżniały sie także wieksszym stopniem umiędzynarodowienia (zagranicznego współautorstwa) niż artykuły z Holandii.

Z perspektywy strategii inteligentnej specjalizacji szczególnie istotne znaczenie ma zaangażowanie przedsiebbiorstw $\mathrm{w}$ prowadzenie i finansowanie działalności badawczorozwojowej. Wielkość i udział nakładów na badania i rozwój oraz zatrudnienia przedsię- biorstw sektora rolno-spożywczego w nakładach i zatrudnieniu ogółem w państwach UE28 (według klasyfikacji ISIC rev. 4) przedstawia tabela 3 . W tabeli 3 przedstawiono także informacyjnie dane dotyczące eksportu sektora rolno-spożywczego.

W obszarze sektora rolno-spożywczego największe nakłady na działalność badawczo-rozwojowa (STAN R\&D expenditures in industry) w 2012 roku poniosły przedsiebiorstwa z Holandii, Francji, Niemiec, Wielkiej Brytanii i Hiszpanii. Największy udział nakładów na działalność badawczo-rozwojową sektora rolno-spożywczego w nakładach ogółem przedsiębiorstw dotyczył Holandii $(7,66 \%)$, Portugalii $(6,57 \%)$ oraz Hiszpanii (4,57\%). Najwięcej pracowników sektora rolno-spożywczego było zatrudnionych $\mathrm{w}$ przedsiębiorstwach $\mathrm{z}$ Francji, Holandii, Niemiec, Hiszpanii, Wielkiej Brytanii i Włoch. Wśród państw Europy Srodkowo-Wschodniej pod wzgledem udziału nakładów na badania i rozwój oraz zatrudnienia pracowników badawczo-rozwojowych wyróżniały się Węgry. Najwięksi eksporterzy sektora rolno-spożywczego to Holandia, Niemcy i Francja, zaś największy udział tego sektora w eksporcie ogółem dotyczył Lotwy, Danii, Grecji, Litwy i Holandii.

Analiza wskaźników ujawnionych przewag w odniesieniu do danych przedstawionych w tabeli 3 oraz państw, dla których dostepne sa dane, wskazuje, że w Niem-

Rysunek 3. Wskaźniki aktywności naukowej w przeliczeniu na pracownika (FTE) w 2012 roku w sektorze rolno-spożywczym (Holandia = 1)

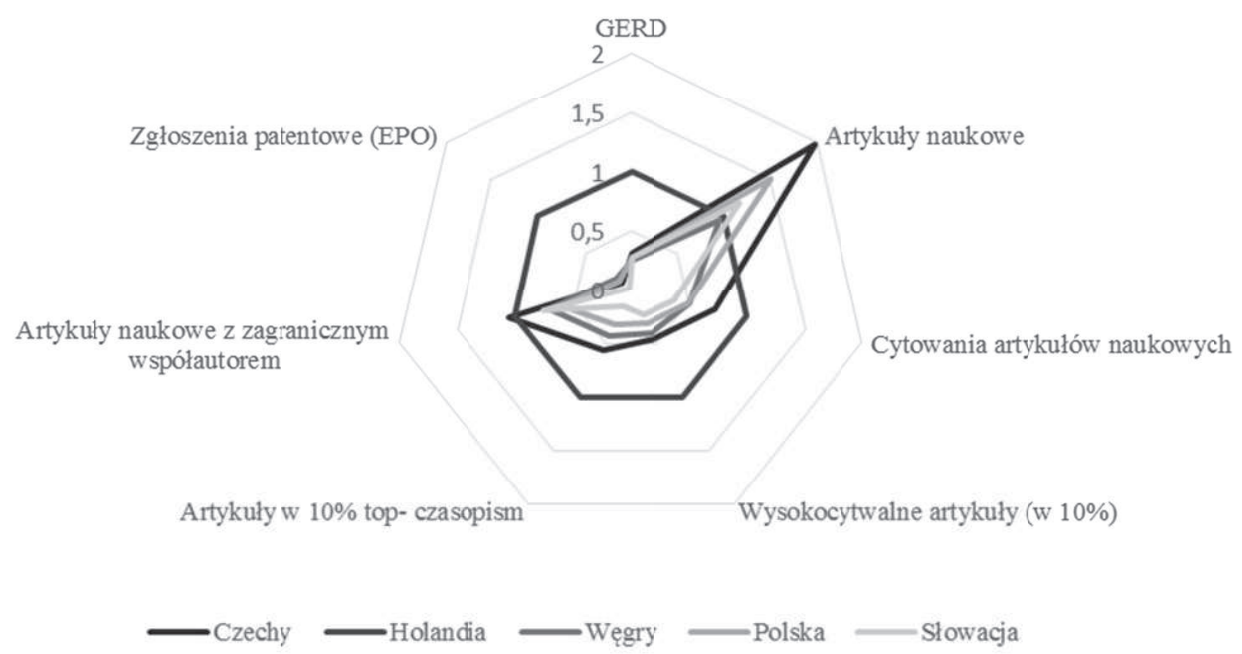

Źródło: opracowanie własne na podstawie danych Scival [23.06.2016] i Eurostat [4.11.2016]. 
Tabela 3. Wielkość i udział nakładów na badania i rozwój, zatrudnienia i eksportu przedsiębiorstw sektora rolno-spożywczego w nakładach, zatrudnieniu i eksporcie ogółem w państwach UE28

\begin{tabular}{|c|c|c|c|c|c|c|}
\hline \multirow[b]{2}{*}{ Państwo } & \multicolumn{2}{|c|}{ Nakłady na B+R } & \multicolumn{2}{|c|}{ Zatrudnienie w B+R } & \multicolumn{2}{|c|}{ Eksport } \\
\hline & $\begin{array}{c}\text { Wielkosć } \\
\text { nakładów } \\
\text { w USD }\end{array}$ & $\begin{array}{c}\text { Udzial } \\
\text { w nakła- } \\
\text { dach } B+R\end{array}$ & $\begin{array}{c}\text { Liczba } \\
\text { zatrudnio- } \\
\text { nych (FTE) }\end{array}$ & $\begin{array}{c}\text { Udzial } \\
\text { w zatrud- } \\
\text { nieniu } \\
\text { w B+R }\end{array}$ & $\begin{array}{c}\text { Eksport } \\
\text { w tys. USD }\end{array}$ & $\begin{array}{c}\text { Udzial } \\
\text { w eksporcie }\end{array}$ \\
\hline Austria & 43994384 & $0,59 \%$ & 394 & $0,85 \%$ & 11795425 & $7,43 \%$ \\
\hline Belgia & 147611147 & $1,92 \%$ & 1300 & $3,41 \%$ & 42797887 & $9,58 \%$ \\
\hline Bułgaria & b.d. & b.d. & b.d. & b.d. & 4316789 & $16,16 \%$ \\
\hline Chorwacja & b.d. & b.d. & b.d. & b.d. & 1683010 & $13,60 \%$ \\
\hline Cypr & b.d. & b.d. & b.d. & b.d. & b.d. & b.d. \\
\hline Czechy & 32440167 & $1,12 \%$ & 456 & $1,42 \%$ & 8022443 & $5,13 \%$ \\
\hline Dania & 86596689 & $1,79 \%$ & 605 & $1,68 \%$ & 22841668 & $21,53 \%$ \\
\hline Estonia & 2448781 & $0,61 \%$ & 38 & $1,88 \%$ & 1954707 & $10,76 \%$ \\
\hline Finlandia & 66924699 & $1,31 \%$ & 449 & $1,45 \%$ & 2998082 & $4,11 \%$ \\
\hline Francja & 593047714 & $1,68 \%$ & 5198 & $2,11 \%$ & 74906610 & $13,41 \%$ \\
\hline Grecja & b.d. & b.d. & $36^{*}$ & $0,52 \%$ & 6706520 & $19,07 \%$ \\
\hline Hiszpania & 470985828 & $4,57 \%$ & 3532 & $3,95 \%$ & 45613307 & $15,95 \%$ \\
\hline Holandia & 652777186 & $7,66 \%$ & 5120 & $6,67 \%$ & 95053775 & $17,21 \%$ \\
\hline Irlandia & 95891191 & $3,94 \%$ & 626 & $3,66 \%$ & 12758029 & $10,83 \%$ \\
\hline Litwa & b.d. & b.d. & b.d. & b.d. & 5584358 & $18,83 \%$ \\
\hline Luksemburg & b.d. & b.d. & b.d. & b.d. & 1499334 & $10,92 \%$ \\
\hline Łotwa & b.d. & b.d. & b.d. & b.d. & 2840771 & $22,39 \%$ \\
\hline Malta & b.d. & b.d. & b.d. & b.d. & 266735 & $4,72 \%$ \\
\hline Niemcy & 576875238 & $0,84 \%$ & 3886 & $1,06 \%$ & 84389736 & $5,98 \%$ \\
\hline Polska & 50827110 & $1,74 \%$ & 579 & $2,25 \%$ & 22500226 & $12,53 \%$ \\
\hline Portugalia & 127820434 & $6,57 \%$ & 537 & $3,43 \%$ & 6818218 & $11,73 \%$ \\
\hline Rumunia & 15917353 & $2,35 \%$ & 151 & $1,39 \%$ & 5216345 & $9,01 \%$ \\
\hline Slowenia & 7979365 & $0,70 \%$ & 105 & $1,11 \%$ & 1208518 & $4,46 \%$ \\
\hline Słowacja & 4090436 & $0,88 \%$ & 93 & $2,44 \%$ & 4806592 & $6,02 \%$ \\
\hline Szwecja & 69040530 & $0,74 \%$ & $418^{*}$ & $0,76 \%$ & 8714661 & $5,05 \%$ \\
\hline Węgry & 78513309 & $4,21 \%$ & 1156 & $5,78 \%$ & 9985664 & $9,69 \%$ \\
\hline Wielka Brytania & 415478236 & $1,69 \%$ & 3156 & $1,97 \%$ & 30428362 & \\
\hline Włochy & 229176277 & $1,58 \%$ & 2164 & $1,80 \%$ & 41404645 & $8,26 \%$ \\
\hline
\end{tabular}

b.d. - brak danych; * - część danych objętych tajemnicą statystyczną

Źródło: opracowanie własne na podstawie danych OECD.Stat [6.11.2016].

czech, Włoszech czy Wielkiej Brytanii udział nakładów na badania i rozwój w sektorze rolno-spożywczym był relatywnie niski na tle innych państw (poniżej 1), mimo wysokich nakładów na badania i rozwój przedsiębiorstw sektora rolno-spożywczego. Znajduje to odzwierciedlenie w strukturze gospodarek tych państw, zwłaszcza w wyso- kim udziale innych sektorów w nakładach na badania i rozwój oraz w eksporcie. Wskaźniki ujawnionych przewag osiagnęły natomiast wysoka wartość dla państw z Europy Środkowo-Wschodniej (Rumunia, Węgry, Polska), chociaż tylko Polska charakteryzowała się ujawnioną przewagą $\mathrm{w}$ eksporcie sektora rolno-spożywczego. 


\section{Podsumowanie}

Sektor rolno-spożywczy jako obszary priorytetowe $\mathrm{w}$ krajowych lub regionalnych strategiach inteligentnych specjalizacji zostały wskazane w 24 państwach Unii Europejskiej (według EYE@RIS3). Potwierdza to dużą popularność tego obszaru tematycznego wśród państw Unii Europejskiej. Na podstawie analizy bibliometrycznej (wskániki specjalizacji - ujawnionych przewag naukowych i technologicznych, wskaźniki aktywności naukowej - liczba artykułów naukowych i zgłoszeń patentowych, wskaźniki jakości naukowej - liczba cytowań na artykułów, FWCI) można wskazać trzy grupy państw pod kątem naukowo-technologicznej pozycji sektora rolno-spożywczego. Pierwsza to grupa państw charakteryzujących się dużą aktywnością naukową i patentową (powyżej 5000 artykułów i 200 patentów w 2012 roku) oraz jakością naukową (według analizowanych wskaźników bibliometrycznych), ale bez względnej specjalizacji naukowej i technologicznej (poniżej 1). Druga grupa to państwa o wysokiej specjalizacji naukowej lub technologicznej (powyżej 1500 artykułów lub 30 patentów w 2012 roku) oraz wysokiej jakości naukowej w zakresie sektora rolno-spożywczego. Trzecia grupe tworzą państwa o specjalizacji naukowej albo technologicznej, ale mniejszej aktywności naukowej, a także niższej od wcześniejszych państw jakości naukowej. Grupy te zostały przedstawione w tabeli 4.

W ramach ww. grup interesującym przykładem jest Hiszpania, która została zaliczona do liderów specjalizacji, ale pod względem wolumenu produkcji naukowotechnologicznej zbliża się do liderów skali, chociaż odróżnia się od nich znacznie mniejszą liczbą zgłoszeń patentowych. Z kolei państwa budujące skalę lub spe-

Tabela 4. Grupy państw pod kątem pozycji naukowo-technologicznej sektora rolno-spożywczego

\begin{tabular}{|c|c|c|c|}
\hline & Liderzy skali & Liderzy specjalizacji & $\begin{array}{l}\text { Budujący skalę } \\
\text { lub specjalizację }\end{array}$ \\
\hline Przykłady państw & $\begin{array}{c}\text { Niemcy, Francja, Wielka } \\
\text { Brytania, Włochy }\end{array}$ & $\begin{array}{l}\text { Holandia, Dania, } \\
\text { Hiszpania, Belgia, } \\
\text { Portugalia }\end{array}$ & $\begin{array}{c}\text { Polska, Węgry, Czechy, } \\
\text { Rumunia, Chorwacja }\end{array}$ \\
\hline $\begin{array}{l}\text { Wnioski z anali- } \\
\text { zy bibliometrycz- } \\
\text { nej w odniesie- } \\
\text { niu do sektora } \\
\text { rolno-spożyw- } \\
\text { czego }\end{array}$ & $\begin{array}{l}\text { - Bardzo duża liczba } \\
\text { artykułów i zgłoszeń } \\
\text { patentowych } \\
\text { - Brak ujawnionych } \\
\text { przewag naukowych } \\
\text { lub technologicznych } \\
\text { - Wysoka jakość nauko- } \\
\text { wa } \\
\text { - Duże nakłady na } \\
\text { badania i rozwój } \\
\text { przedsiębiorstw, } \\
\text { ale ich mały udział } \\
\text { w nakładach ogółem } \\
\end{array}$ & $\begin{array}{l}\text { - Duża (lub bardzo duża) } \\
\text { liczba artykułów lub } \\
\text { zgłoszeń patentowych } \\
\text { - Wysokie ujawnione } \\
\text { przewagi naukowe lub } \\
\text { technologiczne } \\
\text { - Wysoka jakość naukowa } \\
\text { - Duże nakłady na bada- } \\
\text { nia i rozwój przedsię- } \\
\text { biorstw i ich duży udział } \\
\text { w nakładach ogółem }\end{array}$ & $\begin{array}{l}\text { - Mała liczba arty- } \\
\text { kułów lub zgłoszeń } \\
\text { patentowych } \\
\text { - Ujawnione przewagi } \\
\text { naukowe i technolo- } \\
\text { giczne } \\
\text { - Niższa jakość nauko- } \\
\text { wa } \\
\text { - Mniejsze nakłady } \\
\text { na badania i rozwój } \\
\text { przedsiębiorstw, cho- } \\
\text { ciaż ich duży udział } \\
\text { w nakładach ogółem }\end{array}$ \\
\hline $\begin{array}{l}\text { Wyzwania strate- } \\
\text { gii inteligentnej } \\
\text { specjalizacji pod } \\
\text { kątem sektora } \\
\text { rolno-spożyw- } \\
\text { czego }\end{array}$ & $\begin{array}{l}\text { „Rywalizacja” sektora } \\
\text { rolno-spożywczego } \\
\text { z innymi dziedzinami } \\
\text { na poziomie krajowym } \\
\text { (potencjał badawczo- } \\
\text { rozwojowy, eksport); } \\
\text { konieczność utrzymania } \\
\text { wiodącej pozycji w skali } \\
\text { europejskiej zaplecza } \\
\text { naukowo-technologicz- } \\
\text { nego }\end{array}$ & $\begin{array}{l}\text { Duże znaczenie sekto- } \\
\text { ra rolno-spożywczego } \\
\text { w wymiarze krajowym } \\
\text { (potencjał badawczo- } \\
\text { rozwojowy, eksport); } \\
\text { poszukiwanie nisz lub } \\
\text { wzmacnianie pozycji na } \\
\text { rynku europejskim, w tym } \\
\text { zaplecza naukowo-tech- } \\
\text { nologicznego }\end{array}$ & $\begin{array}{l}\text { Dylematy sektora rol- } \\
\text { no-spożywczego doty- } \\
\text { czące ich docelowej } \\
\text { pozycji - liderów skali } \\
\text { lub liderów specjali- } \\
\text { zacji, określenie roli } \\
\text { krajowego zaplecza } \\
\text { naukowo-technolo- } \\
\text { gicznego w łańcuchu } \\
\text { wartości }\end{array}$ \\
\hline
\end{tabular}

Źródło: opracowanie własne. 
cjalizację staja przed wyborem w zakresie sektora rolno-spożywczego strategii dużej skali (np. Polska, Rumunia) lub strategii specjalizacji (np. Czechy, Chorwacja). W przypadku Hiszpanii i państw Europy Srodkowo-Wschodniej strategie inteligentnych specjalizacji dają szansę na wybór i ukierunkowanie rozwoju sektora rolnospożywczego pod kątem realizacji określonej strategii działania (skali lub specjalizacji) oraz określenia miejsca tego sektora wśród innych sektorów gospodarki.

Przedstawione w artykule porównania wskazują, że mimo naukowych i technologicznych przewag względnych sektora rolno-spożywczego, aktywność naukowa i technologiczna państw Europy SrodkowoWschodniej mierzona liczbą artykułów naukowych czy zgłoszeń patentowych oraz wielkościa nakładów na badania i rozwój przedsiębiorstw jest mniejsza niż Niemiec, Francji, Wielkiej Brytanii i Włoch. W świetle omawianych wskaźników względnych Niemcy, Francja, Wielka Brytania czy Włochy nie specjalizują się w tematyce sektora rolno-spożywczego, ale dysponują bardzo dużym potencjałem naukowo-technologicznym, czego potwierdzeniem jest duża liczba artykułów naukowych i zgłoszeń patentowych z sektora rolno-spożywczego. Ponadto państwa te identyfikują sektor rolno-spożywczy jako obszary priorytetowe $\mathrm{w}$ strategiach inteligentnych specjalizacji, co oznacza, że różni interesariusze $\mathrm{z}$ tych państw (zwłaszcza przedsiebiorcy) dostrzegają w tych obszarach tematycznych duży potencjał rozwojowy. Dla innych państw o mniejszym potencjale naukowo-technologicznym, zwłaszcza z Europy Środkowo-Wschodniej, oznacza to, że powinny poszukiwać obszarów niszowych umożliwiających odpowiednie wykorzystanie ich potencjału naukowo-technologicznego oraz uwarunkowań społeczno-gospodarczych. Wśród państw, które nie wskazały sektora rolno-spożywczego jako obszaru priorytetowego $\mathrm{w}$ strategiach inteligentnych specjalizacji znalazły sie Bułgaria, Luksemburg, Łotwa i Słowacja, przy czym Bułgaria i Łotwa wyróżniają się ujawnioną przewagą technologiczną (i dużym udziałem w eksporcie sektora rolno-spożywczego), zaś Słowacja ujawnioną przewaga naukową. Wyniki te (podobnie jak w przypadku np. Cypru i Malty) są dyskusyjne z uwagi na mała liczbe zgłoszeń patentowych, a także relatywnie małą liczbę arty- kułów naukowych z tych państw. Niemniej jednak w przypadku Bułgarii i Łotwy silna pozycja eksportowa sektora rolno-spożywczego nie przełożyła się na uwzględnienie tego obszaru w strategiach inteligentnych specjalizacji (może ona wynikać z szczegółowych opisów dokumentów określajacych strategie inteligentnych specjalizacji w tych państwach, ale nie zostały one ujawnione w ramach narzędzia EYE@RIS3).

$\mathrm{Na}$ podstawie przeprowadzonych analiz można wskazać, że Polska jest liderem wśród państw Europy Środkowo-Wschodniej w zakresie aktywności naukowej i technologicznej w sektorze rolno-spożywczym, chociaż polskie artykuły naukowe charakteryzują się niższymi poziomami cytowań oraz wartościami wskaźnika FWCI. Niższy jest także udział polskich artykułów w grupie artykułów o najwyższej cytowalności i artykułów publikowanych w najbardziej rozpoznawalnych na świecie czasopismach. Może to wskazywać, źe polscy autorzy publikuja głównie w krajowych czasopismach, których oddziaływanie (wpływ) jest mniejsze niż czasopism zagranicznych. Jednocześnie czasopisma te były mniej atrakcyjne od zagranicznych dla naukowców $\mathrm{z}$ innych państw. W przypadku Polski rodzi to pytanie o relacje liczby i jakości (oddziaływania) artykułów i czasopism naukowych, w tym nastawienia na parametry ilościowe (np. pod katem systemu oceny parametrycznej). Kwestia ta wymaga jednak bardziej pogłebionych i szczegółowych analiz.

W artykule ograniczono się do analizy podstawowych wskaźników bibliometrycznych opierających się na liczbie artykułów i liczbie cytowań, a także liczbie zgłoszeń patentowych i podstawowych danych dotyczących zatrudnienia i finansowania. Wprawdzie pozwalają one spojrzeć na kwestie specjalizacji naukowej i technologicznej $\mathrm{z}$ różnych perspektyw, ale nie jest to obraz kompleksowy. Poza tym koncentrują się one głównie na ilościowym aspekcie produkcji naukowo-technologicznej, ale bez uwzględnienia oceny jakościowej (eksperckiej), dlatego też na potrzeby tworzenia strategii inteligentnych specjalizacji powinny one być traktowane jako jedno z wielu źródeł informacji (OECD, 2013, s. 167). W przyszłości warto poszerzyć analizy o inne wskaźniki i porównania różnych przekrojów czasowych, a także zastosowanie bardziej zaawansowanych analiz bibliometrycznych, odwołujących się 
np. do metody tech mining łączącej bibliometrię z eksploracją tekstów, metodami ilościowymi i socjometrią (Klincewicz, 2008, s. 32).

Analiza specjalizacji na podstawie klasyfikacji dziedzin nauki i techniki OECD (FoS 2007) może być prowadzona wyłącznie do obszaru sektora rolno-spożywczego, gdyż pozostałe obszary ujete w ramach tej klasyfikacji obejmują wiele bardzo zróżnicowanych poddziedzin. Zaletą wykorzystania klasyfikacji dziedzin nauki i techniki OECD jest możliwość bezpośredniego porównywania danych dotyczących artykułów naukowych oraz nakładów na badania i rozwój, a także zasobów ludzkich w sektorze badawczo-rozwojowym (dzięki czemu nie ma potrzeby stosowania map konwersyjnych). W artykule odniesiono się także do danych klasyfikowanych zgodnie z Międzynarodową Klasyfikacją Patentów (IPC) czy Międzynarodową Standardową Klasyfikacją Rodzajów Działalności (ISIC rev. 4), ale nie były one przedmiotem szczegółowych analiz pod kątem powiązań wymiaru naukowego i technologicznego, stąd w tym przypadku niezbędne będzie prowadzenie bardziej szczegółowych porównań i zastosowania map konwersyjnych. Należy jednak podkreślić, że tworzenie lub rozbudowa tych map jest zadaniem trudnym i wymagającym dużej wiedzy eksperckiej. W odniesieniu do sektora rolno-spożywczego zasadne byłoby także sięgnięcie do bardziej szczegółowych poddziedzin, ale ograniczeniem dla tych analiz może być brak danych na bardziej szczegółowych poziomach agregacji. $\mathrm{Z}$ uwagi na ograniczoną dostępność danych na poziomie regionalnym $\mathrm{w}$ artykule analizowane były dane na poziomie państw (wyjątkiem są dane zgłoszeń patentowych dostępne także na poziomie regionów, zaś dane dotyczące artykułów naukowych wymagają odpowiedniej weryfikacji i porządkowania). W końcu, analizowane dane dotyczyły głównie lat 2009-2012, zaś niektóre $\mathrm{z}$ nich, jak liczba zgłoszeń patentowych lub wielkość nakładów na badania i rozwój, w wielu państwach są głównie efektem aktywności dużych przedsiębiorstw. Natomiast w procesie przedsiębiorczego odkrywania kluczową rolę powinny odgrywać małe i średnie przedsiębiorstwa oraz ich plany rozwojowe na przyszłość. Ograniczenia te, zwłaszcza związane z dostępem do danych, są znanym i szeroko omawianym w litera- turze problemem tego typu analiz (Foray $\mathrm{i}$ in., 2012, s. 68; OECD, 2013, s. 152). Ich przezwyciężenie stanowi duże wyzwanie, ale zarazem otwiera pole do odkrywania nowych możliwości w zakresie prowadzenia polityk opartych na dowodach oraz wspierania procesów przedsiębiorczego odkrywania i tworzenia strategii inteligentnych specjalizacji.

\section{Bibliografia}

Cavicchi, A. i Ciampi Stancova, K. (2016). Food and gastronomy as elements of regional innovation strategies. European Commission, Joint Research Centre, Institute for Prospective Technological Studies, http://dx.doi.org/10.2791/284013.

Colledge, L. i Verlinde, R. (2014). Scival Metric Guidebook. Elsevier Research Intelligence.

Foray, D., Goddard, J., Goenaga, X., Landabaso, M., McCann, P., Morgan, K., Nauwelaers C. i Ortega-Argiles, R. (2012). Guide to Research and Innovation Strategies for Smart Specialsiation (RIS3). Luxemburg: Publications Office of the European Union, http://dx.doi.org/10.2776/65746.

Foray, D. i Goenaga, X. (2013). The Goals of Smart Specialisation. S3 Policy Brief Series, 1.

Czaplicka-Kolarz, K., Bondaruk, J., Trząski, L., Siodłak, Ł., Uszok, E., Wiesner, M., Gieroszka, A., Skalny, A., Markowska, M., Zawartka, P., Sibiga, P. i Krawczyk, W. (2013). Potencjat naukowo-technologiczny inteligentnej specjalizacji województwa śląskiego. Katowice: Główny Instytut Górnictwa. Pozyskano z: http://npf.gig.eu/images/pliki/partnerzy/rezultaty/Zad.1/Podzadanie\%201h_REZULTAT $\% 207 /$ GIG/Raport_rezultat $\overline{\%} 207 \% 20$ GIG_29.08.2014_korekta\%20zespół.pdf.

Kardas, M. (2016). Określanie priorytetów w polityce naukowej i technologicznej a strategia inteligentnej specjalizacji. Katowice: Studia Ekonomiczne. Zeszyty Naukowe Uniwersytetu Ekonomicznego w Katowicach, Nr 272/2016, s. 68-77.

Klincewicz, K. (2008). Polska innowacyjność. Analiza bibliometryczna. Warszawa: Wydawnictwo Naukowe Wydziału Zarządzania UW.

Klincewicz, K., Żemigała, M. i Mijal, M. (2012). Bibliometria $w$ zarzadzaniu technologiami $i$ badaniami naukowymi. Warszawa: Ministerstwo Nauki i Szkolnictwa Wyższego.

Marszakowa-Szajkiewicz, I. (2009). Badania ilościowe nauki. Podejście bibliometryczne $i$ webometryczne. Poznań: Uniwersytet im. Adama Mickiewicza Wydział Pedagogiczno-Artystyczny.

OECD (2006). Podręcznik Frascati. Warszawa: MNiSW. Pozyskano z: http://www.nauka.gov. pl/g2/oryginal/2013_05/08935db1c9f7adf15c087 d07720a984f.pdf. 
OECD (2013). Innovation-driven Growth Regions: The Role of Smart Specialsiation. Paryż: OECD Publishing.

OECD (2015a). The Innovation Imperative. Con tributing to productivity, growth and well-being Paryż: OECD Publishing, http://dx.doi.org/10.1787/ 9789264239814-en.

OECD (2015b). Analysing Policies to Improve Agricultural Productivity Growth, Sustainability. Draft Framework. Paryż: OECD Publishing.

Olechnikcka, A. i Płoszaj, A. (2008). Polska nauka $w$ sieci? Przestrzeń nauki i innowacyjności. Warszawa.

Nazarko, J., Ejdys, J., Gudanowska, A., Leończuk, D., Olszewska, A., Magruk, A., Kuźmicz, K. Jakuszewicz, J., Wasiluk, A. i Wasiluk, A. (2013). Mapa głównych powiązań między nauka, gospodarka i technologiami $w$ kontekście inteligentnej specjalizacji województwa podlaskiego. Białystok: Politechnika Białostocka. Pozyskano z: http://npf.gig.eu/ images/pliki/partnerzy/rezultaty/Zad.1/Podzada-
nie\%201g_REZULTAT\%206/PB/Rezultat_6PB_ RAPORT_28_11_2013.pdf

Rogut, A. i Piasecki, B. (2013). Mapa głównych powia zań między nauka, gospodarka i technologiami w kontekście inteligentnej specjalizacji województwa tódzkiego. Łódź: Społeczna Akademia Nauk. Pozyskano z: http:// npf.gig.eu/images/pliki/partnerzy/rezultaty/Zad.1/ Podzadanie\%201g_REZULTAT\%206/SAN/Rezultat_6SAN_1g_mapa\%20powiązań_SAN.pdf

Sorvik, J., Kleibrink, A. (2015). Mapping Innovation Priorities and Specialsiation Patterns in Europe. S3 Working Paper Series n 08/2015. European Commission, Joint Research Centre, Institute for Prospective Technological Studies.

Van de Velde, E., Debergh, P., Rammer, Ch., Schliessler, P., Gehrke, B., Wassmann, P., de Heide, M., Butter, M., Wydra, S., Som, O. i Weidner, N. (2015). Key Enabling Technologies. Methodology Report. Pozyskano z: https://ec.europa.eu/growth/ tools-databases/kets-tools/sites/default/files/about/ final_report_kets_observatory_en.pdf. 